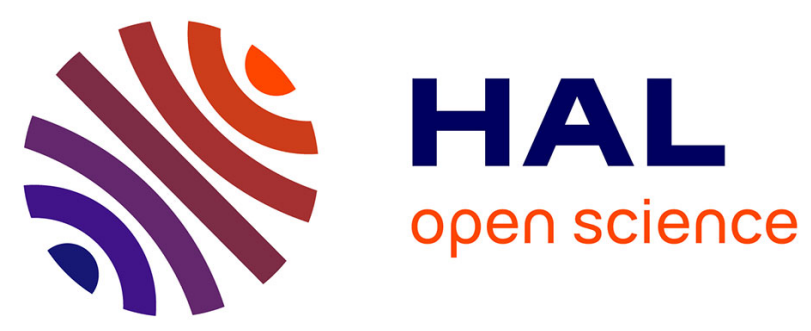

\title{
HPA axis genes may modulate the effect of childhood adversities on decision-making in suicide attempters.
}

Sebastien Guillaume, Nader Perroud, Fabrice Jollant, Isabelle Jaussent, Emilie Olié, Alain Malafosse, Philippe Courtet

\section{To cite this version:}

Sebastien Guillaume, Nader Perroud, Fabrice Jollant, Isabelle Jaussent, Emilie Olié, et al.. HPA axis genes may modulate the effect of childhood adversities on decision-making in suicide attempters.: decision-making and stress. Journal of Psychiatric Research, 2012, epub ahead of print. 10.1016/j.jpsychires.2012.10.014 . inserm-00759957

\section{HAL Id: inserm-00759957 https://www.hal.inserm.fr/inserm-00759957}

Submitted on 3 Dec 2012

HAL is a multi-disciplinary open access archive for the deposit and dissemination of scientific research documents, whether they are published or not. The documents may come from teaching and research institutions in France or abroad, or from public or private research centers.
L'archive ouverte pluridisciplinaire HAL, est destinée au dépôt et à la diffusion de documents scientifiques de niveau recherche, publiés ou non, émanant des établissements d'enseignement et de recherche français ou étrangers, des laboratoires publics ou privés. 


\section{HPA axis genes may modulate the effect of childhood adversities on decision-making in suicide attempters}

\section{Running title: decision-making and stress}

Sebastien Guillaume MD,PhD ${ }^{1,2,3} *$, Nader Perroud MD,PhD ${ }^{4} *$, Fabrice Jollant MD,PhD ${ }^{6}$, Isabelle Jaussent Msc ${ }^{2,3}$, Emilie Olié MD ${ }^{1,2,3}$, Alain Malafosse MD,PhD ${ }^{4,5}$, Philippe Courtet $\mathrm{MD}, \mathrm{PhD}{ }^{1,2,3}$

1. INSERM U1061, Montpellier, France

2. University of Montpellier 1, Montpellier, France

3. CHU Montpellier, Hôpital Lapeyronie, Psychiatric Emergency and Post Emergency Department, Pole Urgence. Montpellier, France

4. Department of Psychiatry, University of Geneva, Switzerland

5. Department of Medical Genetic and Laboratories, University Hospitals of Geneva, Switzerland

6. McGill Group for Suicide Studies, Douglas Mental Health University Institute, McGill University, Montreal, Québec, Canada

* These two authors contributed equally to the work

Corresponding author: Dr Sébastien Guillaume. Psychiatric Emergency and Post Emergency Department, Hopital Lapeyronie, Avenue Gaston Giraud, 34295 Montpellier cedex 5 France. Tel: +33467338581 ; fax: +33467338988

E-mail: guillaumesebastien@ymail.com

Word count for text: 3194

Word count for abstract: 199

Figure: 2

Table: 3 


\begin{abstract}
Decision-making impairment is found in several neuropsychiatric disorders, including suicidal behavior, and has been shown to be modulated by genes. On the other hand, early trauma has been associated with poor mental health outcome in adulthood, in interaction with genetic factors, possibly through sustained alterations in the hypothalamo-pituitary-adrenal axis (HPA axis). Here, we aimed to investigate the effect of childhood trauma and its interaction with HPA-axis related genes on decision-making abilities in adulthood among $\boldsymbol{a}$ sample of suicide attempters. The Iowa Gambling Task (IGT) was used to assess decisionmaking in 218 patients with a history of suicide attempt. Participant fulfilled the Childhood Trauma Questionnaire to report traumatic childhood experiences. Patients were genotyped for single-nucleotide polymorphisms within $C R H R 1$ and $C R H R 2$ genes. Patients with a history of sexual abuse had significantly lower IGT scores than non-sexually abused individuals. Polymorphisms within CRHRI and CRHR2 genes interacted with both childhood sexual abuse and emotional neglect to influence IGT performance. In conclusion, childhood sexual abuse and emotional neglect may have long-term effects on decision-making through an interaction with key HPA axis genes. Even if these results need to be replicated in other samples, impaired decision-making may thus be the dimension through which child maltreatment, in interaction with HPA axis related genes, may have a sustained negative impact on adult mental health.
\end{abstract}

Key words: Child abuse, Gene Environment Interaction, Stress, Decision-making, Attempted suicide. 


\section{Introduction}

Altered decision-making can lead to disadvantageous and sometimes disastrous consequences in life (Damasio, 1994). A large number of studies aimed at understanding the mechanisms of normal and altered decision-making and its development.

Available data suggest a gradual development of decision-making processes during childhood and adolescence with the progressive acquisition of skills to project into the future (Overman, 2004). However, little is known on how childhood traumatic events may affect this developmental process. In humans, there is only one study suggesting that childhood trauma may be associated with lower decision-making abilities (Stoltenberg et al., 2011). This study did not find any interactions between some polymorphisms in the serotonin transporter gene and childhood abuse on decision-making performance. Nevertheless, decision-making abilities may be a major putative endophenotype of mental disorders (Courtet et al., 2011) and has been found to be under the influence of genes encoding proteins involved in neurotransmitter and neurotrophic systems (da Rocha et al., 2011, Jollant et al., 2007, Ness et al., 2011, Roussos et al., 2008, Stoltenberg and Vandever, 2010). This justifies further study on interaction between gene and early environment.

The long-term effects of childhood trauma include alterations in stress systems (Turecki et al., 2012). Childhood maltreatment has been linked to permanent alteration of the hypothalamicpituitary-adrenal (HPA) axis (Heim and Binder, 2011) with damaging effects on the developing brain which may lead to behavioral problems later in life (Champagne et al., 2008, De Bellis et al., 1999b). CRH type 1 receptors (CRHR1) are believed to mediate the effect of the HPA axis on adult psychopathology (Nemeroff et al., 1988, Merali et al., 2004). Several studies investigated the role of $\mathrm{CRH}$ and its receptors CRHR1 in the etiology of psychiatric disorders. They found that polymorphisms within the genes coding for CRHR1 may modulate the effect of early life adverse events on the risk of adulthood psychopathology (Bradley et al., 2008, Ben-Efraim et al., 2011, Polanczyk et al., 2009). HPA axis-related genes therefore represent candidate genes to investigate the interactive effect of genes and early trauma on decision-making abilities as it has been hypothesized (Turecki et al., 2012).

Among the known vulnerability traits specifically associated with suicidal behavior are a history of childhood abuse (Brodsky and Stanley, 2008), impaired decision-making (Jollant et al., 2005) and a dysregulation of the HPA axis (Coryell and Schlesser, 2001). Moreover, stress-regulatory genes, such as CRHRl, may underlie the increased susceptibility of some individuals towards suicidal behavior (Ben-Efraim et al., 2011, Wasserman et al., 2008, Wasserman et al., 2009). In addition, child maltreatment may permanently impact on the HPA 
axis though epigenetic modifications of the glucocorticoid receptor gene in suicide attempters and completers (Perroud et al., 2012, McGowan et al., 2009) Thus, suicide attempters represent a population of choice to investigate the interplay of genes and early environment on decision-making.

We hypothesized that childhood maltreatment would be negatively associated with adult decision-making performance, and that it would interact with polymorphisms within HPA axis related genes to modulate decision-making abilities among a sample of suicide attempters.

\section{Material and Methods}

\section{Population}

Two hundred and eighteen suicide attempters were recruited from consecutive admissions to the university hospital of Montpellier (France) following a suicide attempt. All participants were Caucasian. This sample is part of a large ongoing multi-centre study of suicidal behavior, which has been approved by the local research ethics committee and conducted according to the tenets of the Declaration of Helsinki. After having received information on the study, potential participants completed and returned a consent form. During their hospitalization patients were assessed for psychiatric diagnoses using the Mini International Neuropsychiatric Interview (MINI) (Sheehan et al., 1998). Subjects with a lifetime history of substance use disorders, with a history of alcohol use disorders in the last 6 months or who received electroconvulsive therapy (ECT) were non included. In addition, they fulfilled the Childhood Trauma Questionnaire (CTQ), which examines five types of trauma in a self-report assessment: sexual abuse, physical abuse, physical neglect, emotional abuse and emotional neglect. Scores range from 5 to 25 for each type of trauma. According to Bernstein and Fink (Bernstein and Fink, 1998), thresholds or cut-off scores have been set for each type of trauma at four levels of maltreatment: None, Low, Moderate and Severe. They were reassessed in a second time (in the limit of 6 months after the patient had been discharged from hospital) for a follow-up visit. At this time, all participants were then assessed with the 21-item Hamilton Depression Rating Scale and the Young Mania Rating Scale to ensure that they were normothymic at the time of evaluation. If the participants were euthymic (score below 7 for both scales), they performed the NART that was used to measure general (verbal) cognitive abilities (Mackinnon et al., 1999) and the IGT. 


\section{The Iowa Gambling Task}

Decision-making skills were tested using the computerized version of the Iowa Gambling Task (IGT) as previously described (Bechara et al., 2000). All participants were task-naïve. Briefly, subjects have to make a choice between four decks of cards. Each card results either in a gain only or in a gain and then a loss of money. The goal of the game is to win as much money as possible and the game ends after 100 choices. The participants are unaware of this latter information and of the fact that there are two long-term advantageous decks ("safe decks") for which little money is won but even less is lost (leading to a net gain) and two disadvantageous decks ("risky desks") for which wins are high but losses higher (resulting in a net loss). As the participants are unaware that they lose money, they have therefore to learn from experience to avoid risky decks. The task emphasizes the learning of reward and punishment associations. No real money was given in relation to task performance. The recording of the choices has been made by a computer.

Three scores were computed: the IGT net score was calculated as the difference between the total number of advantageous and disadvantageous choices; the IGT 1-50 and the IGT 51-100 scores examined the difference between the number of advantageous and disadvantageous choices in the beginning of the game (choices 1 to 50) and in the most critical part of the game (choices 51 to 100) as previously reported (Jollant et al., 2007); and five subscores by block of 20 choices (IGT_20) examined learning over the task. For the latter, blocks were analyzed as a continuum in order to examine learning over the task using linear mixed models.

\section{Genotypes}

Genomic DNA was extracted from blood using the Nucleon_BACC 3 kit (Amersham plc, Buckinghamshire, UK). Four SNPs in CRHR1 (rs242948, rs1396862, rs878886, and rs4076452) and 2 in CRHR2 (rs255098 and rs2270007) were genotyped. Four of the SNPs were selected as they were previously studied by others in the context of depression and anxiety disorders (Bradley et al., 2008, Keck et al., 2008, Papiol et al., 2007). Primers and PCR conditions used are available upon request. The amplified products were then digested with A $\mu 1 w N I$ (rs242948), PstI (rs1396862), BgII (rs878886), BbsI (rs4076452), BstEII (rs2270007) and BsrBI (rs255098) and separated on a 2.5\% agarose gel. Genotypes were verified independently by two investigators.

\section{Statistical analysis}


To analyze the effects of genetic variants and childhood maltreatments as well as their interaction on IGT_20, we used a linear mixed model with fixed effects of linear and quadratic functions of time (5 time points), level of education and a random effect of individual, fitted with maximum likelihood as described elsewhere (Uher et al., 2009, RabeHesketh and Skrondal, 2005). The individual-specific random intercept was added to relax the assumption of conditional independence in the responses of the same person. Linear regression with level of education as covariate was used for IGT net, IGT 1-50 and IGT 51100 scores.

Genotypes were analyzed under additive model. As previously done, for statistical purposes and to enhance the power of tests, all cases of childhood trauma were pooled in two categories: not abused or not neglected vs. abused or neglected individuals (by pooling low, moderate and severe abused/neglected subjects) (Perroud et al., 2008, Perroud et al., 2010)

The results of regression models are presented as standardized regression coefficients $(\beta)$ with 95\% confidence intervals which can be interpreted as effect size.

\section{Threshold for significance}

As we evaluated the impact of six polymorphic markers on decision making and also their interaction with childhood maltreatment on modulating IGT scores, a correction for multiple testing was required. Given the presence of a LD block comprising three of the SNPs within CRHR1 (Figure 1) and a relative high LD between the two SNPs within CRHR2, we considered three tests for these polymorphisms. Two additional tests were considered for the interaction with childhood maltreatment and because a high correlation between abuse and neglect was expected (most of the sexually abused subjects also reporting emotional abuse for instance). For multiple tests correction, we therefore used $\mathrm{p}=0.05 /(5+2)=0.007$ as a threshold for significance. Associations detected at $\mathrm{p}<0.05$ were reported as suggestive findings of interest.

Second, we applied the false discovery rate (FDR) by calculating the q-value for each of the tests using the step-up procedure described by Benjamin and Hochberg and modified by Li et al. (Benjamini and Hochberg, 1995). The FDR quantifies the expected proportion of false negatives among multiple findings and the q-value calculated in this way is a good alternative for multiple related tests in genetic association studies.

\section{Results}




\section{Demographic and clinical characteristics of the study group}

Table 1 shows the clinical and demographic characteristics of the 218 suicide attempters. All subjects were euthymic at the time of the assessment but none of them were free of a lifetime axis I diagnosis. All, but 19 subjects, had a history of childhood maltreatment as indicated by the CTQ scores. The mean IGT net score was 4.31 (SD 26.2) and this performance was not affected by age or gender. Conversely, there was a significant positive association between IGT net score and level of education $(b=0.19 ; p=0.005 ; 95 \%$ CI from 0.06 to 0.32$)$ and NART score $(b=0.19 ; p=0.01 ; 95 \%$ CI from 0.05 to 0.33$)$. As NART and educational level strongly co-varied, only educational level was added as a covariate in the subsequent analyses.

Fifty-one participants were free of medication at the time of the assessment. 22 participants had one medication at the time of the assessment (antidepressant n=16;mood stabilizer $n=5$; benzodiazepine $n=1$ ). 29 participants had two treatments (antidepressant + benzodiazepine $n=7$; antidepressant + mood stabilizer $n=16 ;$ mood stabilizer + other such as hypnotic or antipsychotics with no indication as mood stabilizer $n=5$; $\operatorname{mood}$ stabilizer+ benzodiazepine $n=1$ ). 116 participants had 3 or 4 psychotropic medication at the time of the assessment.

\section{Effect of child abuse on decision-making}

There was an association between IGT net score and self-reported childhood sexual abuse: sexually abused individuals had lower scores than non-sexually abused subjects $(b=-0.29$, $\mathrm{p}=0.05 ; 95 \%$ CI from -0.61 to $0 ; 7.12[\mathrm{SD}=26.7]$ vs $-0.16[\mathrm{SD}=25.3])$.

When looking at performance during the first and the second part of the game, no association was found for the first part of the game (IGT 1-50) $(b=-0.09: p=0.577 ; 95 \%$ CI from -0.41 to 0.23). On the second part of the game (IGT 51-100), this association was significant $(b=-0.31$; $\mathrm{p}=0.028 ; 95 \% \mathrm{CI}$ from -0.59 to -0.03 ) and remained significant after adjustment on educational level. This association was also observed for the IGT_20 ( $b=-0.17 ; p=0.05$; $95 \%$ CI from -0.36 to 0$)$.

There was no other association between childhood maltreatment and IGT measures.

To further explore the link between childhood sexual abuse and decision-making, we split the participants into two groups according to an IGT cut-off score of 10 . Thus, 31.3\% ( $\mathrm{N}=67)$ of participants were classified as good performers and $68.7 \%(\mathrm{~N}=147)$ as low performers. Among subjects with childhood sexual abuse, 23.4\% ( $\mathrm{N}=18)$ were good performers and $76.6 \%(\mathrm{~N}=59)$ were low performers; conversely, in the group of subjects who did not self- 
report childhood maltreatment $(\mathrm{N}=19), 42.1 \%(\mathrm{~N}=8)$ were good performers and $58 \%(\mathrm{~N}=11)$ were low performers.

\section{Effect of genotypes on decision-making}

No tested genotypes were significantly associated with IGT measures.

There was no association between any studied genotype and childhood maltreatment.

\section{Gene-environment interaction on decision-making}

There was a significant interaction between the CRHRI SNPs rs1396862, rs878886 and rs242948 and childhood sexual abuse on the IGT net scores (Table 2). The strongest and most significant interaction concerned rs1396862 ( $b=0.78 ; \mathrm{p}=0.008 ; 95 \%$ CI from 0.21 to 1.36 ) (Figure 2), particularly for the IGT 51-100 score $(b=0.81 ; p=0.006 ; 95 \%$ CI from 0.24 to 1.38). This interaction was also observed for IGT_20 ( $b=0.49 ; p=0.003 ; 95 \% C I$ from 0.17 to 0.85) (Figure 2), and was still significant after adjustment on baseline scores. This interaction showed that sexually abused subjects who carry the $\mathrm{T}$ allele (or $\mathrm{G}$ allele for rs878886 [r2=1]) improved their scores from cards 41-60 to cards 81-100 whereas sexually abused subjects who are homozygous for the $\mathrm{C}$ allele worsened $(\mathrm{b}=0.42 ; \mathrm{p}=0.027 ; 95 \% \mathrm{CI}$ from 0.05 to 0.79 ).

The rs255098 within CRHR2 significantly interacted with emotional neglect on IGT net score $(b=0.72 ; p=0.004 ; 95 \% \mathrm{CI}$ from 0.23 to 1.21 ). This interaction was also observed for IGT_20 ( $b=0.45 ; \mathrm{p}=0.003 ; 95 \% \mathrm{CI}$ from 0.15 to 0.75 ) (Figure 3 ). This interaction was mainly explained by the fact that carriers of the AA genotype who were not emotionally neglected better improved than carriers of the GG genotype who were not emotionally neglected $(b=-$ $0.25 ; \mathrm{p}=0.042 ; 95 \% \mathrm{CI}$ from -0.50 to -0.009 ) whereas the opposite was true for emotionally neglected subjects $(b=0.22 ; p=0.068 ; 95 \% \mathrm{CI}$ from -0.02 to 0.47$)$. This interaction was still significant after adjustment on baseline scores, and was mainly explained by the second part of the game (IGT 51-100) $(b=0.73 ; p=0.004 ; 95 \%$ CI from 0.24 to 1.22$)$.

Overall, the three most significant results when considering IGT net scores had a q-value of 0.079 , suggesting that these findings were unlikely to be false.

To ensure that our results were not better accounted by the existence of lifetime Axis I disorders and/or the type of suicide attempt (violent or non-violent), these variables were added as covariates in a secondary analysis. The results were not changed.

\section{Discussion}

In the present study, we found that childhood sexual abuse and childhood emotional neglect interacted with $C R H R 1$ and $C R H R 2$ gene polymorphisms, respectively, to modulate 
adult decision-making in this sample of suicide attempters. This study is therefore the first one to report a negative interaction effect of genes and childhood trauma on the development of decision processes.

Individuals who were homozygous for the C allele of the rs1396862 SNP of CRHRI and sexually abused in their childhood were more likely to choose options with high immediate reward, but with disadvantageous long-term outcome. These individuals seemed unable to learn from past experiences, as suggested by their lack of improvement during the task. Conversely, individuals who carried the $\mathrm{T}$ allele and had a history of childhood sexual abuse more frequently learned how to avoid the disadvantageous options (risky card decks) and thus opted for choices with low immediate reward, but long-term gains, similarly to patients without self-reported sexual abuse. Moreover, our results confirm and broaden previous findings showing that $C R H R 1$ is a key gene in the gene-environment interactions that modulate the effects of childhood abuse on adulthood outcome. Several previous studies showed that specific polymorphisms and haplotypes within CRHRI modulate the effect of child abuse on depression in adults. For instance, Bradley et al. (Bradley et al., 2008) reported that several SNPs within CRHRI interacted with child abuse to predict depressive symptoms. Tyrka et al. (Tyrka et al., 2009) found that CRHRI SNPs moderate the effect of childhood maltreatment on the cortisol responses in the Dexamethasone/CRH test. Several other lines of evidence clearly suggest that CRHRI interacts with early life events (Ben-Efraim et al., 2011, Grabe et al., 2010, Heim et al., 2009) to predict adulthood outcome, in accordance with our findings.

Finally, we also found a more complex interaction involving emotional neglect and the rs255098 SNP in CRHR2. CRHR2, like CRHR1, plays a role in the HPA axis stress response (Coste et al., 2000) and a haplotype variation in the CRHR2 gene has already been associated with suicidal behavior (De Luca et al., 2007). Our results suggest that CRHR2 may also interact with childhood maltreatment to predict adulthood phenotypes.

In humans as well as in animals, the response to stress, and particularly to childhood trauma, is mediated by the HPA axis. Early life stress can induce persistent changes in CRH neurotransmission and alterations of the HPA axis (Heim et al., 2000, De Bellis et al., 1999a). Similarly, early adverse events might also affect the serotonin (5-HT) system. For instance, in animals, early adverse experiences are not only associated with hyperactivity of the CRH system in adults, as indicated by the elevated cerebrospinal fluid (CSF) concentration of CRH and altered $C R H$ and $C R H R 1$ mRNA expression and CRH receptor binding (Coplan et al., 1996, Plotsky et al., 2005, Plotsky and Meaney, 1993), but also with low CSF concentration of 5-Hydroxyindoleacetic acid (5-HIAA), the main 5-HT metabolite (Mathew et al., 2002). As 
there is a close anatomical/functional relationship between the $\mathrm{CRH}$ and 5-HT systems (Ruggiero et al., 1999, Kirby et al., 2008), which are both crucial for correct decision-making, and as childhood abuse can strongly affect the activity of the 5-HT system (Antypa and Van der Does, 2010), we could hypothesize that childhood maltreatment in suicide attempters carrying specific $C R H R 1$ and $C R H R 2$ polymorphisms might impair the normal development of these biochemical pathways and consequently lead to altered decision-making abilities in adulthood.

In healthy adults as well as in animal models, stress interferes with decision-making (van den Bos et al., 2009) but also with the behavioral and cognitive functions associated with the decisional process, such as risk-taking behavior and cognitive flexibility ( (ToledoRodriguez and Sandi, 2011) (Ohira et al., 2011)). In addition, a low level of cortisol was associated with the most disadvantageous pattern of decision-making (van Honk et al., 2003). Finally, it has been recently reported that, in former heroin addicts, stress induction can reveal a latent decision-making impairment (Zhang et al., 2011). Altogether these findings may suggest the need of a fine balance between the negative and positive effects of stress for optimum decision-making abilities. Furthermore, in populations with high risk of decisionmaking impairment, stress could reveal latent decision-making frailty even in individuals with no apparent decision-making impairment.

This study has several limitations. We have chosen to focus on a high-risk sample of suicide attempters, who have been known to have higher rates of childhood trauma and are more likely to have dysregulation of the HPA axis. Therefore, caution is needed to extrapolate these results to healthy controls, because our study population was characterized by low decision-making performance and high rate of childhood abuse. Furthermore we cannot exclude that conclusions regarding decision-making in this sample may also be confounded by other factors such as type of axis I comorbid diagnosis. Replication in other populations (healthy controls as well as affective controls) should be explored. Several variables could have influenced our results: 1) axis II disorders are very common both in people with childhood abuse and suicide attempters and were not assessed; 2) medications were not taken into account although a previous study suggested that drug treatments had no significant effects on decision-making assessment in suicide attempters (Jollant et al., 2005). Moreover, although we evaluated the effects of genes that were previously found to interact with child abuse, we genotyped other SNPs within these genes and, therefore, we might have ended up assessing the effect of phenotypes (i.e., gene expression) slightly different from the ones described in the studies on adult depression. Finally, and despite being one of the largest 
studies investigating such an issue, our work had limited statistical power to detect complex interactions involving specific subgroups, such as males and females. Indeed, a gender effect has been consistently found in studies investigating the interaction between CRHRI and early life adverse events (Heim et al., 2009). Unfortunately our sample size did not allow us to perform such an analysis.

In conclusion, our study adds to the growing body of evidence about the interaction of CRHRl with early life adverse events in the etiology of several psychiatric disorders. The originality of our findings lies in the study of a major putative endophenotype, i.e., impairment of decision-making, a cognitive function that might be involved in the pathophysiology of some psychiatric disorders and that was hypothesized to be more closely linked to underlying genetic variants. In addition, we report the involvement of $C R H R 2$ as well. These results need to be replicated in other samples, but they suggest that decisionmaking impairment may thus be the dimension through which child maltreatment, in interaction with HPA axis-related genes, may have an impact on adulthood psychopathologies. This endophenotype may represent an interesting therapeutic target in patients with a history of childhood abuse. Future tailored-made treatments will take into account cognitive and emotional processes and decision-making abilities may be one of them.

\section{Acknowledgments:}

This study received financial support from CHU Montpellier (PHRC UF 7653), Agence Nationale de la Recherche (ANR NEURO 2007 “GENESIS) and by the Swiss National Fund (Grants 320030-112084).

The authors report no financial relationships with commercial interests related to this study.

The authors wish to thanks Misses Camille Laurent and Annukka Jäkälä for data collection, Miss Valerie Macioce for editing and Prs. A. Bechara and A. Damasio for use of the Iowa Gambling Task.

\section{References}

ANTYPA, N. \& VAN DER DOES, A. J. 2010. Serotonin transporter gene, childhood emotional abuse and cognitive vulnerability to depression. Genes Brain Behav, 9, 615-20.

BECHARA, A., TRANEL, D. \& DAMASIO, H. 2000. Characterization of the decision-making deficit of patients with ventromedial prefrontal cortex lesions. Brain, 123 ( Pt 11), 2189-202. 
BEN-EFRAIM, Y. J., WASSERMAN, D., WASSERMAN, J. \& SOKOLOWSKI, M. 2011. Gene-environment interactions between CRHR1 variants and physical assault in suicide attempts. Genes Brain Behav, 10, 663-72.

BENJAMINI, Y. \& HOCHBERG, Y. 1995. Controlling the false discovery rate: a practical and powerful approach to multiple testing. J $R$ Stat Soc, Series B 57, 289-300.

BERNSTEIN, D. P. \& FINK, L. 1998. Childhood Trauma Questionnaire. A Retrospective Self-Report, San Antonio, USA, The Psychological Corporation.

BRADLEY, R. G., BINDER, E. B., EPSTEIN, M. P., TANG, Y., NAIR, H. P., LIU, W., GILLESPIE, C. F., BERG, T., EVCES, M., NEWPORT, D. J., STOWE, Z. N., HEIM, C. M., NEMEROFF, C. B., SCHWARTZ, A., CUBELLS, J. F. \& RESSLER, K. J. 2008. Influence of child abuse on adult depression: moderation by the corticotropin-releasing hormone receptor gene. Arch Gen Psychiatry, 65, 190-200.

BRODSKY, B. S. \& STANLEY, B. 2008. Adverse childhood experiences and suicidal behavior. Psychiatr Clin North Am, 31, 223-35.

CHAMPAGNE, D. L., BAGOT, R. C., VAN HASSELT, F., RAMAKERS, G., MEANEY, M. J., DE KLOET, E. R., JOELS, M. \& KRUGERS, H. 2008. Maternal care and hippocampal plasticity: evidence for experiencedependent structural plasticity, altered synaptic functioning, and differential responsiveness to glucocorticoids and stress. J Neurosci, 28, 6037-45.

COPLAN, J. D., ANDREWS, M. W., ROSENBLUM, L. A., OWENS, M. J., FRIEDMAN, S., GORMAN, J. M. \& NEMEROFF, C. B. 1996. Persistent elevations of cerebrospinal fluid concentrations of corticotropinreleasing factor in adult nonhuman primates exposed to early-life stressors: implications for the pathophysiology of mood and anxiety disorders. Proc Natl Acad Sci U S A, 93, 1619-23.

CORYELL, W. \& SCHLESSER, M. 2001. The dexamethasone suppression test and suicide prediction. Am J Psychiatry, 158, 748-53.

COSTE, S. C., KESTERSON, R. A., HELDWEIN, K. A., STEVENS, S. L., HEARD, A. D., HOLLIS, J. H., MURRAY, S. E., HILL, J. K., PANTELY, G. A., HOHIMER, A. R., HATTON, D. C., PHILLIPS, T. J., FINN, D. A., LOW, M. J., RITTENBERG, M. B., STENZEL, P. \& STENZEL-POORE, M. P. 2000. Abnormal adaptations to stress and impaired cardiovascular function in mice lacking corticotropin-releasing hormone receptor-2. Nat Genet, 24, 403-9.

COURTET, P., GOTTESMAN, II, JOLLANT, F. \& GOULD, T. D. 2011. The neuroscience of suicidal behaviors: what can we expect from endophenotype strategies? Transl Psychiatr, 1.

DA ROCHA, F. F., MALLOY-DINIZ, L., LAGE, N. V. \& CORREA, H. 2011. The relationship between the Met allele of the BDNF Val66Met polymorphism and impairments in decision making under ambiguity in patients with obsessive-compulsive disorder. Genes Brain Behav, 10, 523-9. DAMASIO, A. R. 1994. Descartes' error: emotion, reason, and the human brain, New York. DE BELLIS, M. D., BAUM, A. S., BIRMAHER, B., KESHAVAN, M. S., ECCARD, C. H., BORING, A. M., JENKINS, F. J. \& RYAN, N. D. 1999a. A.E. Bennett Research Award. Developmental traumatology. Part I: Biological stress systems. Biol Psychiatry, 45, 1259-70.

DE BELLIS, M. D., KESHAVAN, M. S., CLARK, D. B., CASEY, B. J., GIEDD, J. N., BORING, A. M., FRUSTACI, K. \& RYAN, N. D. 1999b. A.E. Bennett Research Award. Developmental traumatology. Part II: Brain development. Biol Psychiatry, 45, 1271-84.

DE LUCA, V., THARMALINGAM, S. \& KENNEDY, J. L. 2007. Association study between the corticotropin-releasing hormone receptor 2 gene and suicidality in bipolar disorder. Eur Psychiatry, 22, 282-7.

GRABE, H. J., SCHWAHN, C., APPEL, K., MAHLER, J., SCHULZ, A., SPITZER, C., FENSKE, K., BARNOW, S., LUCHT, M., FREYBERGER, H. J., JOHN, U., TEUMER, A., WALLASCHOFSKI, H., NAUCK, M. \& VOLZKE, H. 2010. Childhood maltreatment, the corticotropin-releasing hormone receptor gene and adult depression in the general population. Am J Med Genet B Neuropsychiatr Genet, 153B, 1483-93. HEIM, C. \& BINDER, E. B. 2011. Current research trends in early life stress and depression: Review of human studies on sensitive periods, gene-environment interactions, and epigenetics. Exp Neurol. HEIM, C., BRADLEY, B., MLETZKO, T. C., DEVEAU, T. C., MUSSELMAN, D. L., NEMEROFF, C. B., RESSLER, K. J. \& BINDER, E. B. 2009. Effect of Childhood Trauma on Adult Depression and Neuroendocrine Function: Sex-Specific Moderation by CRH Receptor 1 Gene. Front Behav Neurosci, 3, 41. 
HEIM, C., NEWPORT, D. J., HEIT, S., GRAHAM, Y. P., WILCOX, M., BONSALL, R., MILLER, A. H. \& NEMEROFF, C. B. 2000. Pituitary-adrenal and autonomic responses to stress in women after sexual and physical abuse in childhood. JAMA, 284, 592-7.

JOLLANT, F., BELLIVIER, F., LEBOYER, M., ASTRUC, B., TORRES, S., VERDIER, R., CASTELNAU, D., MALAFOSSE, A. \& COURTET, P. 2005. Impaired decision making in suicide attempters. Am J Psychiatry, 162, 304-10.

JOLLANT, F., BURESI, C., GUILLAUME, S., JAUSSENT, I., BELLIVIER, F., LEBOYER, M., CASTELNAU, D., MALAFOSSE, A. \& COURTET, P. 2007. The influence of four serotonin-related genes on decisionmaking in suicide attempters. Am J Med Genet B Neuropsychiatr Genet, 144B, 615-24.

KECK, M. E., KERN, N., ERHARDT, A., UNSCHULD, P. G., ISING, M., SALYAKINA, D., MULLER, M. B., KNORR, C. C., LIEB, R., HOHOFF, C., KRAKOWITZKY, P., MAIER, W., BANDELOW, B., FRITZE, J., DECKERT, J., HOLSBOER, F., MULLER-MYHSOK, B. \& BINDER, E. B. 2008. Combined effects of exonic polymorphisms in CRHR1 and AVPR1B genes in a case/control study for panic disorder. Am J Med Genet B Neuropsychiatr Genet, 147B, 1196-204.

KIRBY, L. G., FREEMAN-DANIELS, E., LEMOS, J. C., NUNAN, J. D., LAMY, C., AKANWA, A. \& BECK, S. G. 2008. Corticotropin-releasing factor increases GABA synaptic activity and induces inward current in 5-hydroxytryptamine dorsal raphe neurons. J Neurosci, 28, 12927-37.

MACKINNON, A., RITCHIE, K. \& MULLIGAN, R. 1999. The measurement properties of a French language adaptation of the National Adult Reading Test. International Journal of Methods in Psychiatric Research, 8, 27-38.

MATHEW, S. J., COPLAN, J. D., SMITH, E. L., SCHARF, B. A., OWENS, M. J., NEMEROFF, C. B., MANN, J. J., GORMAN, J. M. \& ROSENBLUM, L. A. 2002. Cerebrospinal fluid concentrations of biogenic amines and corticotropin-releasing factor in adolescent non-human primates as a function of the timing of adverse early rearing. Stress, 5, 185-93.

MCGOWAN, P. O., SASAKI, A., D'ALESSIO, A. C., DYMOV, S., LABONTE, B., SZYF, M., TURECKI, G. \& MEANEY, M. J. 2009. Epigenetic regulation of the glucocorticoid receptor in human brain associates with childhood abuse. Nat Neurosci, 12, 342-8.

MERALI, Z., DU, L., HRDINA, P., PALKOVITS, M., FALUDI, G., POULTER, M. O. \& ANISMAN, H. 2004. Dysregulation in the suicide brain: $m R N A$ expression of corticotropin-releasing hormone receptors and GABA(A) receptor subunits in frontal cortical brain region. J Neurosci, 24, 1478-85.

NEMEROFF, C. B., OWENS, M. J., BISSETTE, G., ANDORN, A. C. \& STANLEY, M. 1988. Reduced corticotropin releasing factor binding sites in the frontal cortex of suicide victims. Arch Gen Psychiatry, 45, 577-9.

NESS, V., ARNING, L., NIESERT, H. E., STUTTGEN, M. C., EPPLEN, J. T. \& BESTE, C. 2011. Variations in the GRIN2B gene are associated with risky decision-making. Neuropharmacology, 61, 950-6.

OHIRA, H., MATSUNAGA, M., KIMURA, K., MURAKAMI, H., OSUMI, T., ISOWA, T., FUKUYAMA, S., SHINODA, J. \& YAMADA, J. 2011. Chronic stress modulates neural and cardiovascular responses during reversal learning. Neuroscience, 193, 193-204.

OVERMAN, W. H. 2004. Sex differences in early childhood, adolescence, and adulthood on cognitive tasks that rely on orbital prefrontal cortex. Brain Cogn, 55, 134-47.

OVERMAN, W. H., FRASSRAND, K., ANSEL, S., TRAWALTER, S., BIES, B. \& REDMOND, A. 2004.

Performance on the IOWA card task by adolescents and adults. Neuropsychologia, 42, 1838-51. PAPIOL, S., ARIAS, B., GASTO, C., GUTIERREZ, B., CATALAN, R. \& FANANAS, L. 2007. Genetic variability at HPA axis in major depression and clinical response to antidepressant treatment. J Affect Disord, 104, 83-90.

PERROUD, N., COURTET, P., VINCZE, I., JAUSSENT, I., JOLLANT, F., BELLIVIER, F., LEBOYER, M., BAUD, P., BURESI, C. \& MALAFOSSE, A. 2008. Interaction between BDNF Val66Met and childhood trauma on adult's violent suicide attempt. Genes Brain Behav, 7, 314-22.

PERROUD, N., JAUSSENT, I., GUILLAUME, S., BELLIVIER, F., BAUD, P., JOLLANT, F., LEBOYER, M., LEWIS, C. M., MALAFOSSE, A. \& COURTET, P. 2010. COMT but not serotonin-related genes modulates the influence of childhood abuse on anger traits. Genes Brain Behav, 9, 193-202.

PERROUD, N., PAOLONI-GIACOBINO, A., PRADA, P., OLIÉ, E., SALZMANN, A., NICASTRO, R., GUILLAUME, S., MOUTHON, D., STOUDER, C., DIEBEN, K., HUGUELET, P., COURTET, 
P. \& MALAFOSSE, A. 2012. Increased methylation of glucocorticoid receptor gene (NR3C1) in adults with a history of childhood maltreatment: a link with the severity and type of trauma.

Trans Psychiatry, In Press.

PLOTSKY, P. M. \& MEANEY, M. J. 1993. Early, postnatal experience alters hypothalamic corticotropinreleasing factor (CRF) mRNA, median eminence CRF content and stress-induced release in adult rats. Brain Res Mol Brain Res, 18, 195-200.

PLOTSKY, P. M., THRIVIKRAMAN, K. V., NEMEROFF, C. B., CALDJI, C., SHARMA, S. \& MEANEY, M. J. 2005. Long-term consequences of neonatal rearing on central corticotropin-releasing factor systems in adult male rat offspring. Neuropsychopharmacology, 30, 2192-204.

POLANCZYK, G., CASPI, A., WILLIAMS, B., PRICE, T. S., DANESE, A., SUGDEN, K., UHER, R., POULTON, R. \& MOFFITT, T. E. 2009. Protective effect of CRHR1 gene variants on the development of adult depression following childhood maltreatment: replication and extension. Arch Gen Psychiatry, 66, 978-85.

RABE-HESKETH, S. \& SKRONDAL, A. 2005. Multilevel and longitudinal modeling using Stata, College Station, Texas, Stata Press.

ROUSSOS, P., GIAKOUMAKI, S. G., PAVLAKIS, S. \& BITSIOS, P. 2008. Planning, decision-making and the COMT rs4818 polymorphism in healthy males. Neuropsychologia, 46, 757-63.

RUGGIERO, D. A., UNDERWOOD, M. D., RICE, P. M., MANN, J. J. \& ARANGO, V. 1999. Corticotropicreleasing hormone and serotonin interact in the human brainstem: behavioral implications.

Neuroscience, 91, 1343-54.

SHEEHAN, D. V., LECRUBIER, Y., SHEEHAN, K. H., AMORIM, P., JANAVS, J., WEILLER, E., HERGUETA, T., BAKER, R. \& DUNBAR, G. C. 1998. The Mini-International Neuropsychiatric Interview (M.I.N.I.): the development and validation of a structured diagnostic psychiatric interview for DSM-IV and ICD-10. J Clin Psychiatry, 59 Suppl 20, 22-33;quiz 34-57.

STOLTENBERG, S. F., LEHMANN, M. K., ANDERSON, C., NAG, P. \& ANAGNOPOULOS, C. 2011.

Serotonin Transporter (5-HTTLPR) Genotype and Childhood Trauma are Associated with Individual Differences in Decision Making. Front Genet, 2, 33.

STOLTENBERG, S. F. \& VANDEVER, J. M. 2010. Gender moderates the association between 5-HTTLPR and decision-making under ambiguity but not under risk. Neuropharmacology, 58, 423-8.

TOLEDO-RODRIGUEZ, M. \& SANDI, C. 2011. Stress during Adolescence Increases Novelty Seeking and Risk-Taking Behavior in Male and Female Rats. Front Behav Neurosci, 5, 17.

TURECKI, G., ERNST, C., JOLLANT, F., LABONTE, B. \& MECHAWAR, N. 2012. The neurodevelopmental origins of suicidal behavior. Trends Neurosci, 35, 14-23.

TYRKA, A. R., PRICE, L. H., GELERNTER, J., SCHEPKER, C., ANDERSON, G. M. \& CARPENTER, L. L. 2009. Interaction of childhood maltreatment with the corticotropin-releasing hormone receptor gene: effects on hypothalamic-pituitary-adrenal axis reactivity. Biol Psychiatry, 66, 681-5.

UHER, R., MAIER, W., HAUSER, J., MARUSIC, A., SCHMAEL, C., MORS, O., HENIGSBERG, N., SOUERY, D., PLACENTINO, A., RIETSCHEL, M., ZOBEL, A., DMITRZAK-WEGLARZ, M., PETROVIC, A., JORGENSEN, L., KALEMBER, P., GIOVANNI, C., BARRETO, M., ELKIN, A., LANDAU, S., FARMER, A., AITCHISON, K. J. \& MCGUFFIN, P. 2009. Differential efficacy of escitalopram and nortriptyline on dimensional measures of depression. Br J Psychiatry, 194, 251-258.

VAN DEN BOS, R., HARTEVELD, M. \& STOOP, H. 2009. Stress and decision-making in humans: performance is related to cortisol reactivity, albeit differently in men and women.

Psychoneuroendocrinology, 34, 1449-58.

VAN HONK, J., SCHUTTER, D. J., HERMANS, E. J. \& PUTMAN, P. 2003. Low cortisol levels and the balance between punishment sensitivity and reward dependency. Neuroreport, 14, 1993-6.

WASSERMAN, D., SOKOLOWSKI, M., ROZANOV, V. \& WASSERMAN, J. 2008. The CRHR1 gene: a marker for suicidality in depressed males exposed to low stress. Genes Brain Behav, 7, 14-9. WASSERMAN, D., WASSERMAN, J., ROZANOV, V. \& SOKOLOWSKI, M. 2009. Depression in suicidal males: genetic risk variants in the CRHR1 gene. Genes Brain Behav, 8, 72-9.

ZHANG, X. L., SHI, J., ZHAO, L. Y., SUN, L. L., WANG, J., WANG, G. B., EPSTEIN, D. H. \& LU, L. 2011. Effects of stress on decision-making deficits in formerly heroin-dependent patients after different durations of abstinence. Am J Psychiatry, 168, 610-6. 
Table 1: Clinical and demographic characteristics of the subjects

\begin{tabular}{|llll|}
\hline Table 1 & $\begin{array}{l}\text { Demographic and clinical characteristics of } 218 \text { suicide } \\
\text { attempters }\end{array}$ & N & \% \\
\hline \hline \multirow{3}{*}{ Gender } & & 154 & 70.64 \\
& Female & 77 & 36.15 \\
& Sexual abuse & 71 & 33.02 \\
CTQ & Physical abuse & 93 & 43.66 \\
& Physical neglect & 134 & 63.81 \\
& Emotional abuse & 169 & 79.72 \\
& Emotional neglect & 154 & 70.64 \\
Diagnoses & Major depressive disorder & 56 & 25.69 \\
& Bipolar disorder & 131 & 68.23 \\
Age & Anxiety disorders & 56 & 25.69 \\
NART & alcohool use disorder & 39.71 & 12.68 \\
Years of education & 23.43 & 4.70 \\
\hline
\end{tabular}


Table 2: IGT net score by genotypes and interactions between childhood maltreatment and SNPs on IGT net score

\begin{tabular}{|c|c|c|c|c|c|c|c|c|c|c|c|}
\hline \multirow[t]{2}{*}{ Gene } & \multirow[t]{2}{*}{$S N P$} & \multirow[t]{2}{*}{$N$} & \multicolumn{4}{|c|}{ IGT total score } & \multirow{2}{*}{$\begin{array}{c}S A^{*} \boldsymbol{G} \\
\mathrm{p}\end{array}$} & \multirow{2}{*}{$\begin{array}{c}P A^{*} \boldsymbol{G} \\
\mathrm{p}\end{array}$} & \multirow{2}{*}{$\begin{array}{c}P N^{*} \boldsymbol{G} \\
\mathrm{p}\end{array}$} & \multirow{2}{*}{$\begin{array}{c}\boldsymbol{E} \boldsymbol{A}^{* \boldsymbol{G}} \\
\mathrm{p}\end{array}$} & \multirow{2}{*}{$\begin{array}{c}E N^{* C} \boldsymbol{C} \\
\mathrm{p}\end{array}$} \\
\hline & & & Mean & SD & $\mathrm{b}$ & $\mathrm{p}$ & & & & & \\
\hline \multirow{13}{*}{ CRHRI } & rs242948 & & & & \multirow{4}{*}{-0.037} & \multirow{4}{*}{0.698} & \multirow{4}{*}{0.025} & \multirow{4}{*}{0.097} & \multirow{4}{*}{0.437} & \multirow{4}{*}{0.500} & \multirow{4}{*}{0.775} \\
\hline & $\mathrm{AA}$ & 68 & 5.85 & 29.15 & & & & & & & \\
\hline & $\mathrm{AC}$ & 100 & 2.90 & 24.36 & & & & & & & \\
\hline & $\mathrm{CC}$ & 47 & 4.30 & 26.46 & & & & & & & \\
\hline & rs878886 & & & & & & & & & & \\
\hline & $\mathrm{CC}$ & 121 & 5.14 & 26.68 & \multirow{2}{*}{-0.047} & \multirow{2}{*}{0.751} & \multirow{2}{*}{0.008} & \multirow{2}{*}{0.356} & \multirow{2}{*}{0.051} & \multirow{2}{*}{0.278} & \multirow{2}{*}{0.711} \\
\hline & $\mathrm{CG}+\mathrm{GG}$ & 97 & 3.28 & 25.70 & & & & & & & \\
\hline & rs1396862 & & & & & & & & & & \\
\hline & $\mathrm{CC}$ & 115 & 5.06 & 27.19 & \multirow{2}{*}{-0.068} & \multirow{2}{*}{0.652} & \multirow{2}{*}{0.008} & \multirow{2}{*}{0.394} & \multirow{2}{*}{0.065} & \multirow{2}{*}{0.301} & \multirow{2}{*}{0.664} \\
\hline & $\mathrm{CT}+\mathrm{TT}$ & 96 & 3.02 & 25.71 & & & & & & & \\
\hline & rs4076452 & & & & & & & & & & \\
\hline & $\mathrm{CC}$ & 158 & 4.00 & 26.46 & \multirow{2}{*}{0.074} & & $0>0$ & 0760 & 0228 & 0007 & 0601 \\
\hline & $\mathrm{CG}+\mathrm{GG}$ & 59 & 5.05 & 25.94 & & .001 & 0.20 & 0.200 & 0.534 & 0.001 & 0.021 \\
\hline & rs255098 & & & & & & & & & & \\
\hline & AA & 80 & 3.75 & 31.46 & & & & & & & \\
\hline & $\mathrm{AG}$ & 100 & 3.74 & 22.08 & 0.021 & 0.846 & 0.962 & 0.274 & 0.056 & 0.192 & 0.004 \\
\hline CRHR2 & GG & 38 & 7.00 & 24.51 & & & & & & & \\
\hline & rs2270007 & & & & & & & & & & \\
\hline & $\mathrm{CC}$ & 146 & 3.00 & 26.81 & 0.42 & 0323 & 0402 & 0182 & 0586 & 0505 & 0023 \\
\hline & $\mathrm{CG}+\mathrm{GG}$ & 67 & 5.91 & 25.10 & $0.14 \mathrm{~J}$ & 0.500 & 0.45 & 0.100 & 0.500 & 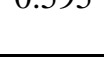 & ני. \\
\hline
\end{tabular}


Figure 1: Linkage Desiquilibrium (LD) r2 between SNPs within $C R H R 1$ and $C R H R 2$

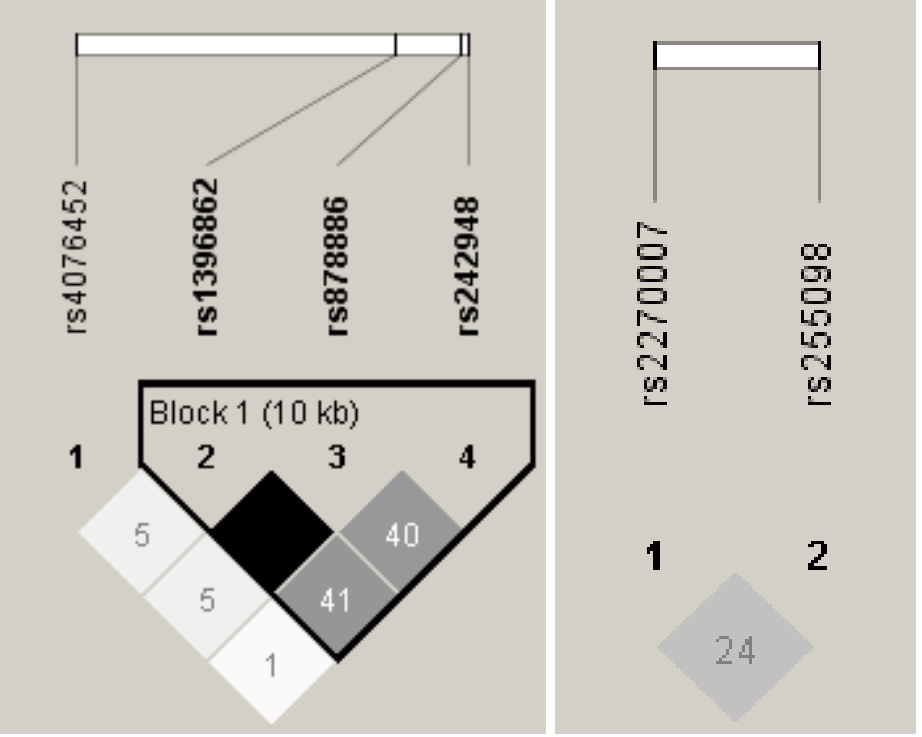


Figure 2: Interaction between rs1396862 within $C R H R I$ and childhood sexual abuse on IGT scores.

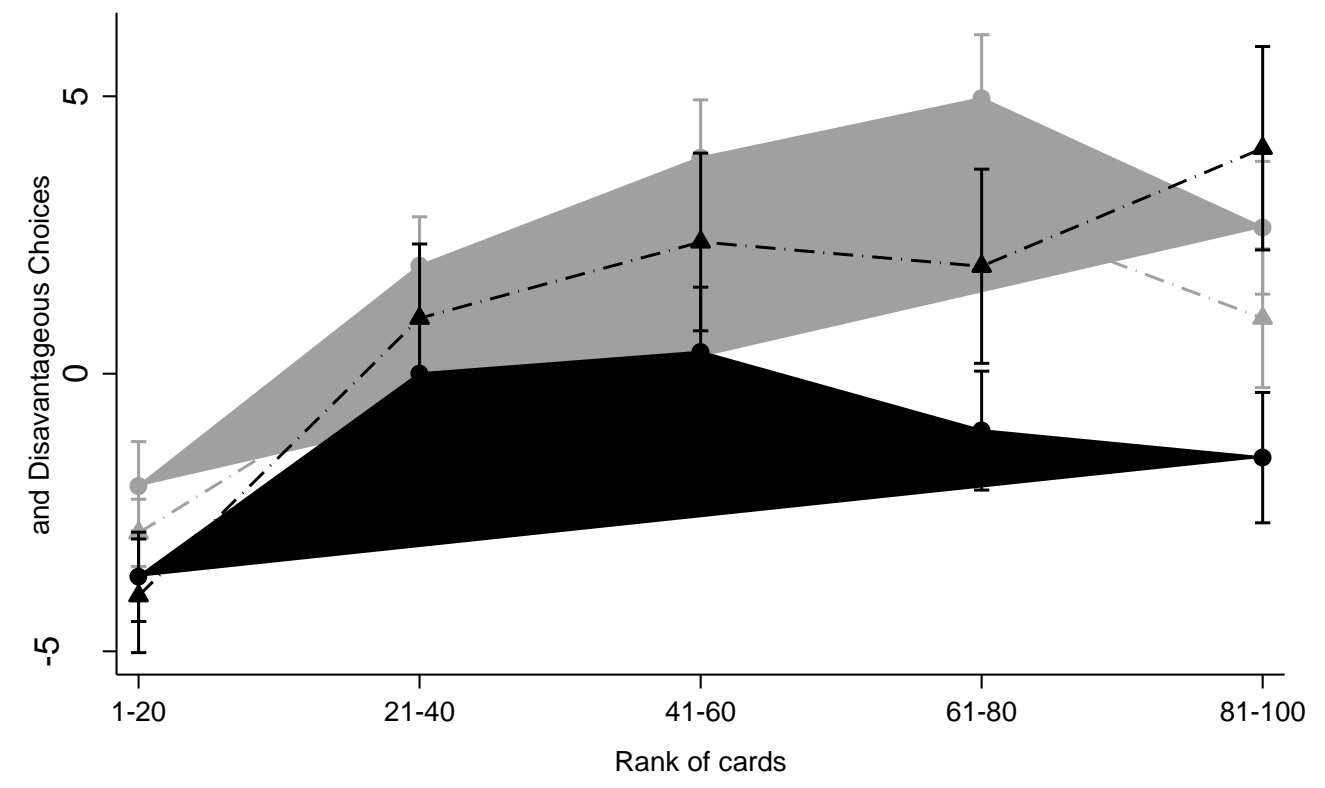

- CC no sexual abuse

$\triangle \mathrm{CT}+\mathrm{TT}$ no sexual abuse

- CC sexual abuse

- CT+TT sexual abuse 
Figure 3: Interaction between rs 255098 within $C R H R 2$ and childhood emotional neglect on IGT scores.

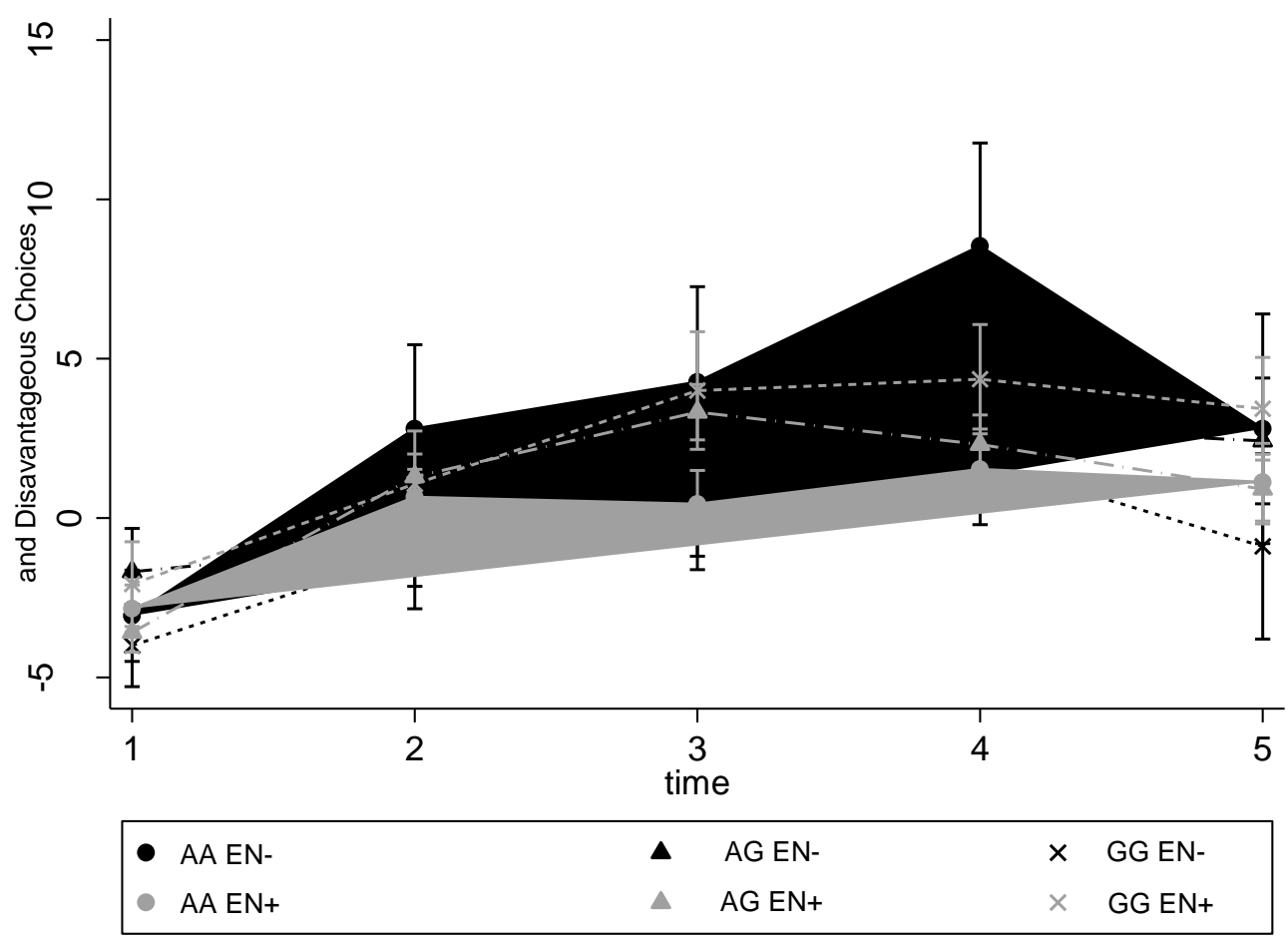

